\title{
An Overview About Ultrastructure of Kranz Anatomy in Cyperaceae (Poales)
}

\author{
Shirley Martins ${ }^{1,4}$, Silvia Rodrigues Machado ${ }^{2}$ and Vera Lucia Scatena ${ }^{3}$
}

\begin{abstract}
An overview about ultrastructure of Kranz anatomy in Cyperaceae (Poales) - The ultrastructure of the Kranz tissues in Cyperaceae species with the four types of Kranz anatomy (chlorocyperoid, eleocharoid, fimbristyloid and rhynchosporoid) was studied and compared with species already described in the literature, with the goal verifying the occurrence of patterns for the Kranz types. In addition, chloroplasts and mitochondria were quantified for the first time for all Kranz types. The chloroplast's structure is similar in the mesophyll cells (PCA) in the four Kranz types, but differs in some features in the bundle sheath cells (PCR). In the chlorocyperoid and rhynchosporoid types the bundle sheath cells (PCR) present centrifugal or scattered chloroplasts with convoluted or parallel thylakoids. In the eleocharoid types, the chloroplasts are scattered with parallel thylakoids. The fimbristyloid type presents centrifugal chloroplasts with convoluted and parallel thylakoids. To eleocharoid and fimbristyloid types and to Cyperus and Pycreus (chlorocyperoid) was observed pattern in the chloroplasts position. In most of the studied species the number of mitochondria in the bundle sheath cells (PCR) is significantly higher than in the mesophyll cells (PCA) and this result diverges from the results found in previous studies.
\end{abstract}

Key words: $\mathrm{C}_{4}$ photosynthesis, chloroplast, mitochondria, Cyperaceae, Kranz.

\section{Introduction}

Species with $\mathrm{C}_{4}$ photosynthesis are in general anatomically characterized by the presence of two types of specialized photosynthetic tissues: the photosynthetic carbon assimilation (PCA) tissue, constituted by the mesophyll cells (chlorophyllian parenchyma) arranged radially, and the photosynthetic carbon reduction (PCR) tissue, constituted by the vascular bundle sheath with chloroplasts (Soros \& Bruhl 2000; Sage 2004; Sage et al. 2011; Sage et al. 2012). However, in some species of Amaranthaceae that presents $\mathrm{C}_{4}$ photosynthesis without Kranz anatomy, in which all photosynthetic process occur within a single chlorenchyma cell (Edwards et al. 2004; Edwards \& Voznesenskaya 2011)

From an ultrastructural point of view, $\mathrm{C}_{4}$ plants differ from $\mathrm{C}_{3}$ ones by the great number of chloroplasts in the bundle sheath cells (PCR), which are absent or fewer in $\mathrm{C}_{3}$ plants (Brown et al. 1983; Sage et al. 2011). The structure of the chloroplasts varies between the two photosynthetic tissues (PCA and PCR) mainly in relation to the thylakoids organization (Brown 1958; Black \& Mollenhauer 1971; Besnard et al. 2009). In addition, the chloroplasts of the PCR tissue can differ in location and organization of the thylakoids system among species from different families or from the same family (Gutierrez et al. 1974; Bruhl \& Perry 1995). In general, these variations are related to the biochemical subtype of the decarboxylation enzymes: NADP-ME; NAD-ME and PCK (Gutierrez et al. 1974; Hatch et al. 1975; Yoshimura et al. 2004).

Cyperaceae is one of the families with the highest numbers of species with $\mathrm{C}_{4}$ photosynthesis

\footnotetext{
${ }^{1}$ Universidade Estadual do Oeste do Paraná (UNIOESTE), Centro de Ciências Biológicas e da Saúde, R. Universitária, Jardim Universitário, 85819-110, C.P. 000711, Cascavel, PR, Brazil.

${ }^{2}$ Universidade Estadual Paulista (UNESP), Inst. Biociências, Depto. Botânica, Botucatu, 18618-000, São Paulo, Brazil.

${ }^{3}$ Universidade Estadual Paulista (UNESP), Inst. Biociências, Depto. Botânica, Rio Claro, 13506-900, São Paulo, Brazil.

${ }^{4}$ Author for correspondence: shirley_botany@yahoo.com.br
} 
(Sage et al. 2011) and includes four Kranz anatomical types (chlorocyperoid, eleocharoid, fimbristyloid and rhynchosporoid) (Soros \& Bruhl 2000). In the family each anatomical type are usually associate with a taxonomic group (chlorocyperoid - tribe Cypereae; eleocharoid - Eleocharis; fimbristyloid - tribe Abildgaardieae; rhynchosporoid-Rhynchospora), but in Eleocharis also occurs species with fimbristyloid type and in Rhynchospora the chlorocyperoid type (Soros \& Bruhl 2000; Martins \& Scatena 2011).

The Kranz types in Cyperaceae differ anatomically in the number and continuity of the vascular bundle sheath and in the presence or not of chloroplasts in the bundle sheath (Soros \& Bruhl 2000; Martins \& Scatena 2011). The fimbristyloid type possesses three bundle sheaths: the outer with thin-walled cells, reduced lumen, and chloroplasts; the middle one has slightly thick-walled cells, reduced lumen, and no chloroplasts; and the inner one (PCR) present thin-walled cells, ample lumen and chloroplasts, being discontinuous in the major veins. In the chlorocyperoid and eleocharoid types the bundles are surrounded by two sheaths: the outer one with slightly thick-walled cells, reduced lumen and no chloroplasts, and the inner one (PCR) with thin-walled cells, large lumen and chloroplast, differing by the continuity of the inner bundle sheath in the major veins only in the eleocharoid type. The rhynchosporoid type differs from the others by the presence of only one sheath (PCR), constituted by thick-walled cells with chloroplasts (Martins \& Scatena 2011).

The origin of the PCA and PCR tissues, besides of the others bundle sheaths were demonstrated by Soros and Dengler (2001) and Martins and Scatena (2011). These studies showed that in Cyperaceae Kranz species the PCA tissues originates from ground meristem and the PCR tissues, in all Kranz types, develops from procambium.

The biochemical subtype of the decarboxylation enzymes (NADP-ME or NAD-ME) also varies in the $\mathrm{C}_{4}$ species of the family (Ueno et al. 1989; Bruhl et al. 1987; Bruhl \& Perry 1995; Voznesenskaya et al. 2005), in which the species of the chlorocyperoid, fimbristyloid (tribe Abildgaardieae) and rhynchosporoid types possess the NADP-ME subtype, and the eleocharoid and fimbristyloid (Eleocharis) types contain the NAD-ME subtype (Bruhl \& Perry 1995; Murphy et al. 2007).

The chloroplast characteristics in groups with $\mathrm{C}_{4}$ photosynthesis might be of great relevance for taxonomy and systematic purposes (Brulh \& Perry
1995; Jacobs 2001). However, in Cyperaceae it is difficult to establish patterns related to the chloroplast structure because of the small number of studied species, mainly in species $\mathrm{C}_{4}$ of Rhynchospora and Eleocharis. The ultrastructural studies with $\mathrm{C}_{4}$ Cyperaceae conducted in species from the four Kranz types have mainly examined species of tribe Cypereae (chlorocyperoid) and tribe Abildgaardieae (fimbristyloid) (Carolin et al. 1977; Ueno et al. 1988; Estelita 1992; Bruhl \& Perry 1995; Rodrigues \& Estelita 2003; Martins et al. 2008). To Rhynchospora, presenting rhynchosporoid and chlorocyperoid Kranz types, some works described the ultrastructural features to Rhynchospora rubra (Lour.) Makino (rhynchosporoid) (Carolin et al. 1977; Bruhl et al. 1987; Bruhl \& Perry 1995) and recently, other Kranz Rhynchospora species with both Kranz types were described by Ueno (2013), however, were used dry material and therefore some characteristic were unclear, leading the author detach the importance of new studies using fresh material. To eleocharoid type the ultrastructural analysis were conducted mainly with Eleocharis vivipara Link and Eleocharis baldwinii (Torr.) Chapm. (Bruhl \& Perry 1995; Ueno 1996; Uchino et al. 1998; Ueno 2004; Murphy et al. 2007).

Quantifying organelles is important for characterizing the cell structure of the different Kranz types, and this process has been performed with several Poaceae species (Brown et al. 1983; Yoshimura et al. 2004). However, in Cyperaceae this approach has only been performed with individuals of Eleocharis vivipara (fimbristyloid) growing in distinct environmental conditions (Ueno 1996). The information about quantifying organelles are considerate important for indicating the biochemical subtype of the decarboxylation enzymes (Bruhl et al. 1987; Ueno 1996) by the proportion of mitochondria present in the mesophyll cells (PCA - Photosynthetic Carbon Assimilative tissue) relative to the bundle sheath cells (PCR - Photosynthetic Carbon Reductive tissue). The majority studied in Cyperaceae only indicated this proportion by visual observation (Carolin et al. 1977; Bruhl et al. 1987; Bruhl \& Perry 1995).

The aim of this study was to characterize and to quantify the chloroplasts and mitochondria of Cyperaceae species with different types of Kranz anatomy, using fresh material, and compared with species already described in the literature to identify if there is pattern to the types and if the similarities can reflect the taxonomical proximity. 


\section{Material and methods}

Eight species of Cyperaceae with different types of Kranz anatomy were studied: Cyperus ligularis L. (S. Martins 280, 330), Kyllinga brevifolia Rottb. (S. Martins 281, 288) and Rhynchospora barbata (Vahl) Kunth (S. Martins 313; V.L. Scatena 321) chlorocyperoid Kranz anatomy; Eleocharis minima Kunth (S. Martins 405, 406) - eleocharoid Kranz anatomy; Bulbostylis scabra (J. Presl. \& C. Presl.) C.B. Clarke (S. Martins 248, 408) and Fimbristylis autumnalis L. (V.L. Scatena 337, 343) - fimbristyloid Kranz anatomy; Rhynchospora globosa Lindl (S. Martins 261,305) and R. terminalis Kunth (S. Martins 250, 302) - rhynchosporoid Kranz anatomy. The species were collected in their natural habitats and the voucher materials were deposited at the Herbarium of the Department of Botany, Universidade Estadual Paulista (HRCB).

Samples of the mid-region of at least three fully expanded leaf blade or scapes (Eleocharis minima) fully developed were fixed in $2.5 \%$ glutaraldehyde solution in $0.1 \mathrm{M}$ phosphate buffer at a $\mathrm{pH}$ of 7.3 for $24 \mathrm{~h}$ at $5^{\circ} \mathrm{C}$, post-fixed with $1 \%$ osmium tetroxide in the same buffer for $1 \mathrm{~h}$ at $25^{\circ} \mathrm{C}$, dehydrated with an acetone series and embedded in Araldite resin. Ultrathin transverse sections were obtained with a Diatome diamond knife and were stained with uranyl acetate and lead citrate (Reynolds 1963). The material was examined with a Philips EM 301 transmission electron microscope (MET). The numbers of chloroplasts and mitochondria per cell were counted for 30-40 cells of the mesophyll cells (PCA) and of the bundle sheath (PCR) in eight vascular bundles of at least three leaves under an electron microscope.

Statistical analyses were performed to verify the significant differences among the number of organelles in the PCA and PCR tissues. A nonparametric test (Wilcoxon/Kruskall-Wallis) was applied using R (R Development Core Team 2010).

\section{Results}

Mesophyll cells (PCA)

In all studied species, the mesophyll cells (Fig. 1a - asterisk), in transverse sections, have generally lenticular chloroplasts located near the cell walls (Fig. $1 b, c)$ and with well-developed grana (Gr) (Fig. 1d). Plasmodesmata $(\mathrm{Pl})$ occur between adjacent PCA cells (Fig. 1e) and also between the PCA cells and adjacent bundle sheath cells. The PCA cells in the studied species differ in the number of chloroplasts (Tab. 2) and in to the development of the peripheral reticulum ( $\mathrm{Pr}$ ), which is well-developed in Eleocharis minima (eleocharoid), Rhynchospora terminalis (rhynchsoporoid) and R. barbata (chlorocyperoid) (Fig. 1f) and which is reduced or absent in the other species. The mitochondria (Mi) in the PCA cells are oval with developed cristae (Fig. 1c).

\section{Bundle sheaths (Chlorocyperoid)}

The Kranz chlorocyperoid species Cyperus ligularis (Fig. 1g), Kyllinga brevifolia (Fig. 1h) and Rhynchospora barbata (Fig. 1i), possess two sheaths around the vascular bundles: the outer one (Os) lacks chloroplasts, whereas the inner one (Is) has larger chloroplasts (PCR) (Fig. 1g, i). In the inner sheath cells (Is), the chloroplasts are located centrifugally in C. ligularis (Fig. 1g), but in K. brevifolia (Fig. 1h) and $R$. barbata (Fig. 1i) they are centrifugal or do not present a pattern of localization (Tab. 1). The lamellar system of the chloroplasts is composed of thylakoids parallel or convoluted in C. ligularis (Fig. 1j), parallel in $K$. brevifolia (Fig. 1k) and parallel or convoluted, sometimes forming concentric cicles, in $R$. barbata (Fig. 11). The peripheral reticulum is reduced or absent (Fig. 1j, k, 1 and Tab. 1). Starch grains were observed only in Kyllinga brevifolia, which can be numerous, large and generally elipsoids (Fig. 1k). The mitochondrias in the PCR cells are usually oval in transverse view (Fig. $1 \mathrm{~m}$ ) and in K. brevifolia and $R$. barbata, they were more numerous in PCR cells than in the PCA cells, while in C. ligularis, the PCR and PCA cells had similar numbers of mitochondria (Tab. 2). Plasmodesmata ( $\mathrm{Pl}$ ) are frequent between the anticlinal walls of the inner sheath cells (Fig. 1m), connecting them, and between the inner sheath cells and the outer bundle sheath cells (Fig. 1i).

\section{Bundle sheaths (Eleocharoid)}

Eleocharis minima possess Kranz elecharoid anatomy and have two vascular bundle sheaths: the outer bundle sheath (Os) lacks chloroplasts, whereas the inner bundle sheath (Is) present chloroplasts (PCR) (Fig. 2a). In the inner sheath cells, the chloroplasts do not show a constant location and ocuppy most of the cell lumen (Fig. 2a). These organeles shows parallel thylakoids (Fig. 2b), reduced peripheral reticulum and few starch grains. Additionally, in these cells, the mitochondria (Mi) are oval or elongate in transverse view (Fig. 2b) and were more numerous compared to those in the mesophyll cells (PCA) (Tab. 2). Plasmodesmata (Pl) occur between the anticlinal walls of the inner sheath cells and between the inner sheath cells and the outer bundle sheath cells. 
Bundle sheaths (Fimbristyloid)

Bulbostylis scabra and Fimbristylis autumnalis have Kranz fimbristyloid anatomy (Fig. 2c), with vascular bundles surrounded by three sheaths: the outer sheath (Os) and the inner sheath (Is) with chloroplasts, while the middle sheath (Ms) lacks chloroplasts (Fig. 2c). In the cells of the outer bundle sheath, the chloroplasts are smaller than those of the PCA cells, but are similar in lenticular shape, welldeveloped grana (Fig. 2d) and reduced peripheral reticulum. In the inner sheath (PCR), the chloroplasts are mainly centrifugal (Fig. 2c, e), with convoluted thylakoids in Bulbostylis scabra and convoluted or parallel thylakoids, sometimes forming concentric cicles, in Fimbristylis autumnalis (Fig. 2e) and a reduced peripheral reticulum. The mitochondria of the inner sheath cells are oval or circular in transverse view with well deveped cristae (Fig. 2e). In these species the mitochondria were more numerous in inner sheath cells (PCR) than in the mesophyll cells (PCA) (Tab. 2). Plasmodesmata (Pl) are frequent among the cells of the different sheaths and between the anticlinal walls of the inner sheath cells. Starch grains were not observed in the PCR cells.

\section{Bundle sheaths (Rhynchosporoid)}

The rhynchosporoid species, Rhynchospora globosa (Fig. 2f) and R. terminalis (Fig. 2g), have vascular bundles surrounded by a single bundle sheath containing chloroplasts (PCR) (Fig. 2f). In the cells of this sheath, the chloroplasts located in general centrifugally (Fig. 2g) and possess usually parallel thylakoids (Fig. 2h, i), a reduced peripheral reticulum and few starch grains. The mitochondria are oval in transverse view and they were observed in similar numbers as those in the mesophyll cells (PCA) (Tab. 2). Plasmodesmata are frequent between the anticlinal walls of the inner sheath cells (Fig. 2i) and between the inner sheath cells and those of the mesophyll cells.

The characteristcs of the organelles in the studied species (Tab. 1) were compared with those species of the literature (Tab. 3) to further the discussion.

\section{Discussion}

The Kranz Cyperaceae species of the four anatomical types studied here and described in the literature (Carolin et al. 1977; Ueno et al. 1988; Bruhl \& Perry 1995) have chloroplasts in the mesophyll cells (PCA) with well-developed grana. These same characteristics was observed in the chloroplasts of the outer bundle sheath cells in the Kranz fimbristyloid species study here and in the literature (Bruhl \& Perry 1995). Therefore, the mesophyll and outer bundle sheath cells in the

Table 1 - Chloroplast features of the vascular bundle sheath cells (PCR) in the Cyperaceae studied species (A = absent; Fd = few developed; $\mathrm{Md}$ = moderately developed)

\begin{tabular}{|c|c|c|c|}
\hline \multirow{2}{*}{ Taxa studied } & \multicolumn{3}{|c|}{ Chloroplast (PCR) } \\
\hline & Thylakoid system & Peripheral Reticulum & Position \\
\hline \multicolumn{4}{|l|}{ Chlorocyperoid } \\
\hline \multicolumn{4}{|l|}{ Cypereae } \\
\hline Cyperus ligularis & convoluted & A & centrifugal \\
\hline Kyllinga brevifolia & convoluted/parallel & $\mathrm{Fd}$ & centrifugal/scattered \\
\hline \multicolumn{4}{|l|}{ Rhynchosporeae } \\
\hline Rhynchospora barbata & contorted/parallel & $\mathrm{Fd}$ & centrifugal/scattered \\
\hline \multicolumn{4}{|l|}{ Eleocharoid } \\
\hline \multicolumn{4}{|l|}{ Scirpeae } \\
\hline Eleocharis minima & parallel & Md & scattered \\
\hline \multicolumn{4}{|l|}{ Fimbristyloid } \\
\hline \multicolumn{4}{|l|}{ Abildgaardieae } \\
\hline Bulbostylis scabra & convoluted/parallel & A & centrifugal \\
\hline Fymbristylis autumnalis & convoluted/parallel & A & centrifugal \\
\hline \multicolumn{4}{|l|}{ Rhynchosporoid } \\
\hline \multicolumn{4}{|l|}{ Rhynchosporeae } \\
\hline Rhynchospora globosa & parallel (contorted) & A & centrifugal/scattered \\
\hline Rhynchospora terminalis & parallel (contorted) & A & centrifugal/scattered \\
\hline
\end{tabular}




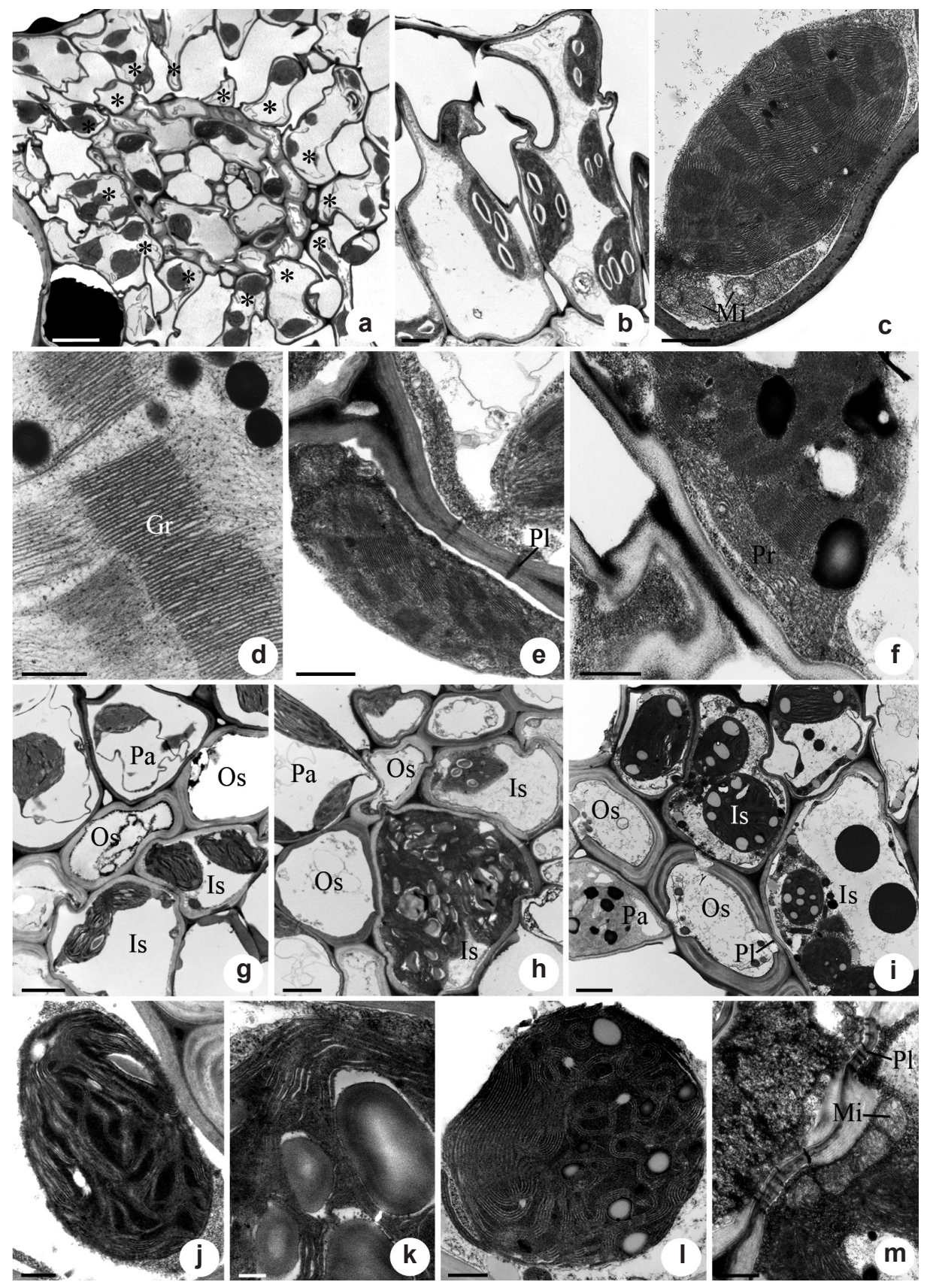

Figure 1 - a-f. transmission electron micrographs of leaves of Cyperaceae species with Kranz anatomy in transverse sections showing the radiate parenchyma cells (PCA). g-m.vascular bundle sheaths cells (PCR). a, d, g,j. Cyperus ligularis (chlorocyperoid) - a. general view of the vascular bundle showing the arrangement of radiate parenchyma cells (PCA); $d$. detail of the grana in the chloroplast; g. general view of the bundle sheaths; j. detail of the chloroplasts in the inner bundle sheath. b, e, h, k, m. Kyllinga brevifolia (chlorocyperoid) - b. PCA cells with chloroplasts; e. plasmodesmata between the PCA cells; $h$. general view of the bundle sheaths; $\mathrm{k}$. detail of the chloroplasts in the inner bundle sheath; $\mathrm{m}$. detail of the inner bundle sheath cells showing the mitochondria and plasmodesmata. c. Fimbristylis autumnalis (fimbristyloid) - Chloroplasts and mitochondria of the PCA cells. f, i, 1. Rhynchospora barbata (chlorocyperoid) - f. detail of the peripheral reticulum of the chloroplast; i. general view of the bundle sheaths; 1. detail of the chloroplasts in the inner bundle sheath. Symbols: Asterisk, radiate parenchyma cells; Gr, grana; Is, inner bundle sheath; Mi, mitochondria; Os, outer bundle sheath; $\mathrm{Pa}$, radiate parenchyma cells; $\mathrm{Pl}$, plasmodesmata; Rp, peripheral reticulum. Scale bars: (a) $=5 \mu \mathrm{m}$; (b), (g-i) $=2 \mu \mathrm{m} ;$ (c) and (e) $=1 \mu \mathrm{m}$; (d), (f), (j), (l-m) $=0.5 \mu \mathrm{m} ;(\mathrm{k})=0.2 \mu \mathrm{m}$. 
fimbristyloid type, that present the same origin (Martins \& Scatena 2011), can be interpreted as having similar functions as indicated by Carolin et al. (1977).

The variations in location and structure of chloroplats in the bundle sheath cells, that constitute the PCR tissue, observed in the species studied here (Tab. 1) also was observed in others studied species (Tab. 3), differing in some aspects (Tabs. 1, 3).

Pattern to chloroplast location only can be indicated to eleocharoid and fimbristyloid (tribe Abildgaardieae) types (Tabs. 1, 3) in the Cyperaceae Kranz species. To the others types this character varies (Tabs. 1, 3) and then it cannot be applied in taxonomical context to taxa with these Kranz types. According to Hattersley \& Browning (1981), the chloroplast location can be related with the photosynthetic activities and the centrifugal position facilitate the transport of metabolites. Therefore, the centrifugal chloroplasts position in all fimbristyloid species from the Abildgaardieae described can be influenced by the distance between the PCR and PCA, because this Kranz type is the unique type with three bundle sheaths. In the others Kranz types with two (chlorocyperoid and eleocharoid) or one sheaths (rhynchosporoid) is more common the scattered distribution.

Yet as to the fimbristyloid type (tribe Abildgaardieae), thylakoid system organization was described as convoluted or contorted (Tab. 3 ), but in the species studied here also occur the parallel organization (Tab. 1). The occurrence of convoluted and contorted thylakoids has been related to the increase to the stromal area (Carolin et al. 1977; Rodrigues \& Estelita 2003).

In the Kranz chlorocyperoid species, that included members of tribe Cypereae (Cyperus ligularis and Kyllinga brevifolia) and tribe Rhynchosporeae (Rhynchospora barbata) from present study and literature, it was not possible establish a pattern because of variation in the chloroplast position, development of the peripheral reticulum and the organization of the thylakoid system (Tabs. 1, 3). Nevertheless, within the tribe Cypereae, the Kranz Cyperus and Pycreus species had chloroplasts in the centrifugal position (Tab. 3), representing a potential taxonomic character and reflecting similarity between the genera, already indicated by Tucker (1994), who grouped all species of these genera within Cyperus.
The similarity observed about the chloroplast location and structure in Eleocharis species with eleocharoid (Tabs. 1, 3) or fimbristyloid (Tab. 3) types can be interpreted as a pattern to the Kranz species of the genus and can be useful to the taxonomy of this group.

The characteristics of the chloroplasts in Rhynchospora species from both Kranz types (chlorocyperoid and rhynchosporoid) are generally similar in position, thylakoid system organization and the development of the peripheral reticulum (Tabs. 1, 3). So, these features can be considerate common to Kranz species of the genus.

The peripheral reticulum constitutes a series of anastomosed tubules located in the stroma periphery of the chloroplast (Laestch 1974) and present taxonomic values to Kranz Cyperaceae species (Ueno et al. 1988; Bruhl \& Perry 1995). However, in the studied species here and from the literature, the degree of peripheral reticulum development is varied, even in close groups (Tabs. 1, 3), remaining constant only in Kranz Rhynchospora.

Some authors indicated that the variations in the chloroplast location (centripetal or centrifugal), organization of thylakoids system (with or without grana developed) and ratios of mitochondria quantity between the PCA and PCR tissues in Poaceae and Cyperaceae species can be related with the biochemical subtypes (NADP-ME or NADME) (Hatch et al. 1975; Hattersley \& Browning 1981; Bruhl \& Perry 1995). In Poaceae, the species with NADP-ME subtype present centrifugal chloroplasts with reduced or absent grana and similar ratios of mitochondria between the PCA and PCR tissues (Hatch et al. 1975; Hattersley \& Browning 1981). Whereas in NAD-ME species, the chloroplasts are centripetal, with grana developed and major number of mitochondria in the PCR tissues (Hatch et al. 1975; Hattersley \& Browning 1981).

About the chloroplast location, in the Kranz species of Cyperaceae studied here (Tab. 1) and described in the literature (Tab. 2), they present centrifugal distribution only in the fimbristyloid (tribe Abildgaardieae) and chlorocyperoid (Cyperus, Pycreus) types. These Kranz types were indicated to present NADP-ME subtype (Ueno et al., 1989; Bruhl \& Perry 1995), corroborating the same chloroplast location observed in NADPME Poaceae species (Hattersley \& Browning 1981). However, other Kranz Cyperaceae species, 


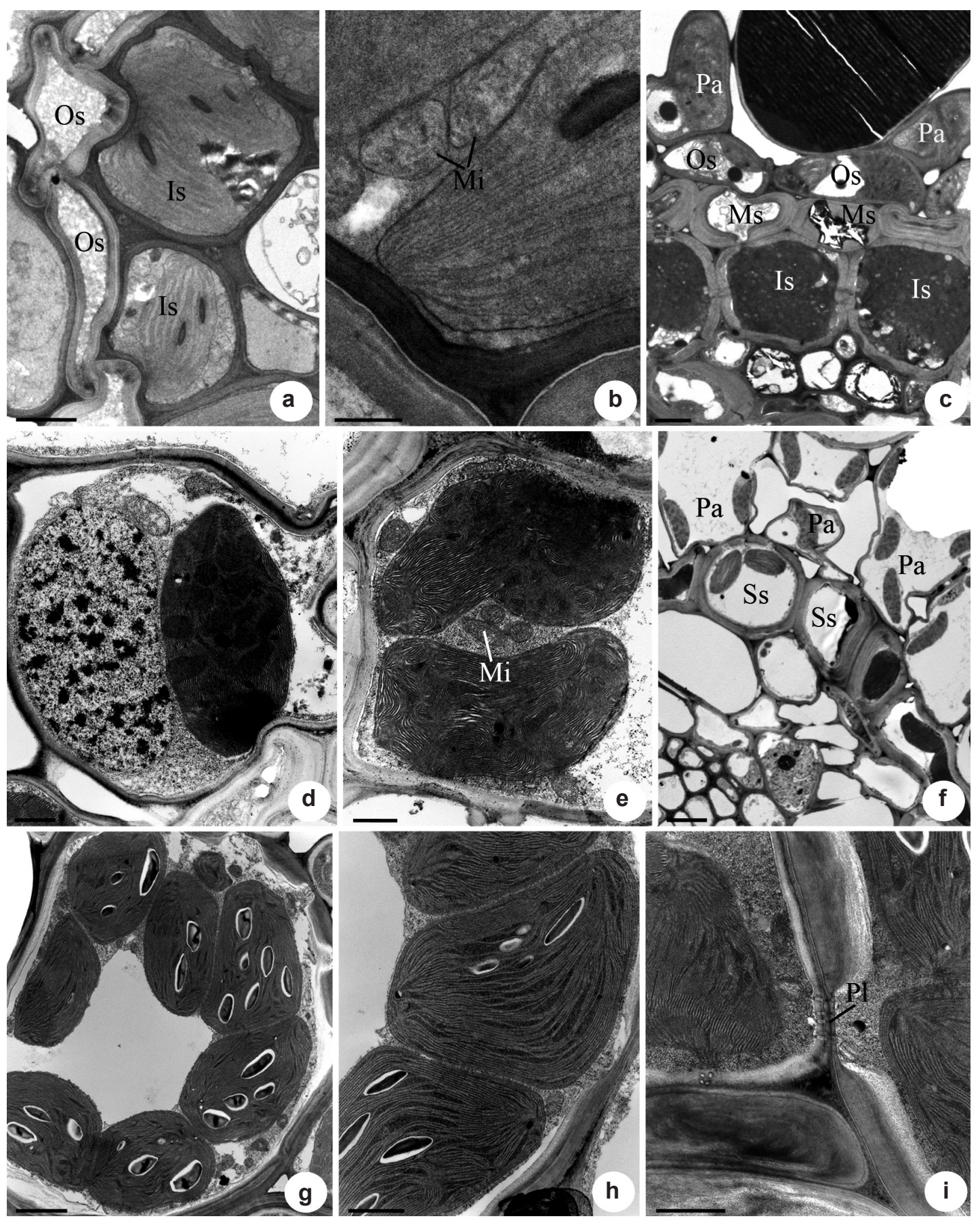

Figure 2 - Transmission electron micrographs of leaves of Cyperaceae species with Kranz anatomy in transverse sections showing the vascular bundle sheaths cells. a-b. Eleocharis minima (eleocharoid) - a. general view of the bundle sheaths; b. detail of the chloroplasts and mitochondria in the inner bundle sheath. c. Bulbostylis scabra (fimbristyloid) - general view of the bundle sheaths. d-e. Fimbristylis autumnalis (fimbristyloid) - detail of the chloroplasts in the outer bundle sheath and in the inner bundle sheath, respectively. f. Rhynchospora globosa (rhynchosporoid) - general view of the bundle sheaths. g-i. Rhynchospora terminalis (rhynchosporoid) - g-h. general view and detail of the chloroplasts in the inner bundle sheath, respectively; i. plasmodesmata between the inner bundle sheath cells. Symbols: Mi, mitochondria; Ms, middle bundle sheath; Os, outer bundle sheath; Pa, radiate parenchyma cells; Ss, single bundle sheath; Is, inner bundle sheath; Pl, plasmodesmata. Scale bars: (f) $=5 \mu \mathrm{m}$; (a), (c), (g) $=2 \mu \mathrm{m}$; (d-e), (h) =1 $\mu \mathrm{m}$; (b) and (i) $=0.5 \mu \mathrm{m}$. 
Table 2 - Number of chloroplasts and mitochondria in the PCR and PCR tissues of Cyperaceae studied species. Values are given as means $\pm \mathrm{SD}$. Asterisks represent significant difference at $\mathrm{P}<0.05$ between the PCA and PCR cells and ns represent not significant difference. $(\mathrm{PCA}=$ Primary Carbon Assimilation tissue; $\mathrm{PCR}=$ Photosynthetic Carbon Redution tissue)

\begin{tabular}{|c|c|c|c|c|c|}
\hline \multirow{2}{*}{ Taxa studied } & \multicolumn{2}{|c|}{ Radiate Parenchyma (PCA) } & \multicolumn{2}{|c|}{ Bundle sheath (PCR) } & \multirow{2}{*}{$\begin{array}{c}\text { Mitochondria } \\
\text { (PCR:PCA) }\end{array}$} \\
\hline & Chloroplast & Mitochondria & Chloroplast & Mitochondria & \\
\hline \multicolumn{6}{|l|}{ Chlorocyperoid } \\
\hline \multicolumn{6}{|l|}{ Cypereae } \\
\hline Cyperus ligularis & $2.7 \pm 0.9$ & $2.2 \pm 1.6$ & $1.5 \pm 0.6^{*}$ & $2 \pm 0.7^{\mathrm{ns}}$ & $\sim 1$ \\
\hline Kyllinga brevifolia & $2.9 \pm 1.1$ & $2.5 \pm 0.8$ & $2.2 \pm 0.8$ & $5.6 \pm 1.7 *$ & $>1$ \\
\hline \multicolumn{6}{|l|}{ Rhynchosporeae } \\
\hline Rhynchospora barbata & $3.1 \pm 1.7$ & $1.9 \pm 2.2$ & $2.9 \pm 0.8^{\mathrm{ns}}$ & $5.5 \pm 3.3 *$ & $>1$ \\
\hline \multicolumn{6}{|l|}{ Eleocharoid } \\
\hline \multicolumn{6}{|l|}{ Scirpeae } \\
\hline Eleocharis minima & $2.5 \pm 1.1$ & $3 \pm 1$ & $2.3 \pm 1.2^{\mathrm{ns}}$ & $7.7 \pm 5.1 *$ & $>1$ \\
\hline \multicolumn{6}{|l|}{ Fimbristyloid } \\
\hline \multicolumn{6}{|l|}{ Abildgaardieae } \\
\hline Bulbostylis scabra & $3.8 \pm 1.2$ & $2.9 \pm 0.8$ & $3.3 \pm 0.9^{\mathrm{ns}}$ & $5.8 \pm 1.4 *$ & $>1$ \\
\hline Fimbristylis autumnalis & $2.5 \pm 0.9$ & $1.8 \pm 1.2$ & $2,2 \pm 0.5^{\mathrm{ns}}$ & $2.2 \pm 1.7^{*}$ & $>1$ \\
\hline \multicolumn{6}{|l|}{ Rhynchosporoid } \\
\hline \multicolumn{6}{|l|}{ Rhynchosporeae } \\
\hline Rhynchospora globosa & $3.3 \pm 0.8$ & $1.8 \pm 0.9$ & $1.9 \pm 0.7 *$ & $1.7 \pm 0.9^{\mathrm{ns}}$ & $\sim 1$ \\
\hline R. terminalis & $4.6 \pm 2.0$ & $3.6 \pm 1.9$ & $3.9 \pm 2.0^{\mathrm{ns}}$ & $3.7 \pm 2.5^{\mathrm{ns}}$ & $\sim 1$ \\
\hline
\end{tabular}

Table 3 - Chloroplast features of the vascular bundle sheath cells (PCR) and ratio of mitochondria between the PCA and PCR tissues of Cyperaceae species described in previous studies $(\mathrm{A}=$ absente; $\mathrm{Fd}=$ few developed; $\mathrm{Md}=$ moderately developed; PCA = Primary Carbon Assimilation tissue; PCR = Photosynthetic Carbon Redution tissue; $\mathrm{Wd}=$ well developed)

\begin{tabular}{|c|c|c|c|c|}
\hline \multirow{2}{*}{ Genera Kranz } & \multicolumn{3}{|c|}{ Chloroplast (PCR) } & \multirow{2}{*}{$\begin{array}{c}\text { Mitochondria } \\
\text { (PCR:PCA) }\end{array}$} \\
\hline & Thylakoid system & Peripheral Reticulum & Position & \\
\hline \multicolumn{5}{|l|}{ Chlorocyperoid } \\
\hline \multicolumn{5}{|l|}{ Cypereae } \\
\hline Cyperus $^{2,3,5,6,7}$ & contorted/convoluted & Fd to $\mathrm{Wd}$ & centrifugal & $\sim 1$ \\
\hline Pycreus ${ }^{1,7}$ & convoluted & Md & centrifugal & $\sim 1$ \\
\hline Remirea $^{4}$ & parallel & $\mathrm{Wd}$ & centripetal & not seen \\
\hline Rhynchospora ${ }^{10}$ & convoluted & $\mathrm{Fd}$ & unclear & not seen \\
\hline \multicolumn{5}{|l|}{ Eleocharoid } \\
\hline \multicolumn{5}{|l|}{ Scirpeae } \\
\hline Eleocharis $^{1,8,9}$ & parallel & $\mathrm{Fd}$ to $\mathrm{Md}$ & scattered & $>1$ \\
\hline \multicolumn{5}{|l|}{ Fimbristyloid } \\
\hline \multicolumn{5}{|l|}{ Abildgaardieae } \\
\hline Bulbostylis ${ }^{7}$ & convoluted & $\mathrm{Fd}$ & centrifugal & $\sim 1$ \\
\hline Fimbristylis ${ }^{1,2,3,7}$ & contorted/convoluted & $\mathrm{Fd}$ to $\mathrm{Md}$ & centrifugal & $\sim 1$ \\
\hline $\begin{array}{l}\text { Rhynchosporoid } \\
\text { Rhynchosporeae }\end{array}$ & & & & \\
\hline Rhynchospora ${ }^{1,7,10}$ & convoluted/parallel & A to $\mathrm{Fd}$ & centrifugal/scattered & $\sim 1$ \\
\hline
\end{tabular}

${ }^{1}$ Bruhl \& Perry (1995); ${ }^{2}$ Carolin et al. (1977); ${ }^{3}$ Estelita-Teixeira \& Handro (1987); ${ }^{4}$ Estelita (1993); ${ }^{5}$ Kim et al. (1999); ${ }^{6}$ Rodrigues \& Estelita (2003); ${ }^{7}$ Ueno et al. (1988); ${ }^{8}$ Ueno (1996); ${ }^{9}$ Ueno (2004); ${ }^{10}$ Ueno (2013) 
such as rhynchosporoid (Rhynchospora) and chlorocyperoid (Kyllinga) types, also indicated to have NADP-ME (Ueno et al. 1989; Bruhl et al. 1987), the distribution of the chloroplast in PCR cells can be scattered or without location pattern (Tabs. 1, 3). Only Kranz Eleocharis species were indicated to have NAD-ME biochemical subtypes (Bruhl et al. 1987; Bruhl \& Perry 1995), but different from those Poaceae species with this subtype, the chloroplasts do not present location pattern (Tabs. 1, 3).

In relation to the ratios of mitochondria between the PCA and PCR tissues (Hatch et al. 1975; Hattersley \& Browning 1981), in Kyllinga brevifolia and Rhynchospora barbata (chlorocyperoid) and in Bulbostylis scabra and Fimbristylis autumnalis (fimbristyloid), the number of mitochondria was significantly greater in the PCR cells relative to the PCA cells, even these Kranz types being indicated to have NAPD-ME. To Rhynchospora species from the both Kranz types (chlorocyperoid and rhynchosporoid) was indicated no significant increase in the number of mitochondrias in the PCR cells in relation to the PCA cells (Ueno et al. 1988; Bruhl \& Perry 1995; Ueno 2013). This indication is in accord with our observations only to rhynchosporoid species. Thus, the centrifugal localization of the chloroplasts in the PCR cells and the similar ratio of mitochondria between PCA and PCR do not represent consistent characteristcs for indicating the biochemical subtype NADP-ME in the Cyperaceae different from that described to NADP-ME Poaceae species.

The species of the Eleocharis genus studied here (Tab. 1) and described in the literature (Tab. 3) present chloroplast without location pattern (Tab. 1) or scattered (Tab. 3) and have been indicated to possess the NAD-ME biochemical subtype (Bruhl \& Perry 1995), differing from the Poaceae species with this subtype that possess centripetal chloroplast (Hattersley \& Browning 1981; Yoshimura et al. 2004). Thus, the data observed here show that the characteristics of location, thylakoids organization and mitochondria ratios between PCA and PCR tissues that were indicated as useful traits to distinguish NADP-ME and NADME biochemical subtypes to Poaceae, in general, cannot be applied to Cyperaceae.

The dimorphism between PCA and PCR tissues was corroborated in the present study, in which the PCA cells possess chloroplast with welldeveped grana and PCR cells show chloroplasts with grana absent or reduced (parallel thylakoids). The characterization and quantificafion of chloroplasts and mitochondria amplify the knowledge about the different types of Kranz anatomy in Cyperaceae, showing that Kranz species of the eleocharoid, rhynchosporoid and fimbristyloid types, have patterns in relation to chloroplast position and/or thylacoids organization. In addition, to the genera Cyperus, Eleocharis, Pycreus and Rhynchospora some characters can be useful for future studies of their systematics. To Cyperus and Pycreus the similarities in the chloroplast structure reinforce the proximity of these genera. To Eleocharis and Rhynchospora species with different Kranz types show similarities in chlroplasts location and organization of thylacoids.

\section{Acknowledgements}

We thank the Fundação de Amparo à Pesquisa do Estado de São Paulo - FAPESP for a PhD grant (2008/09380-2) to S. Martins and financial support (2011/18275-0) and the Conselho Nacional de Desenvolvimento Científico e Tecnológico - CNPq for financial support to V. L. Scatena (301692/2010-6 and 471837/2011-3) and to S. R. Machado (2008/301464-1) and the Centre of Microscopy of the Universidade Estadual Paulista (Botucatu).

\section{References}

Besnard, G.A.; Muasya, M.; Russier, F.; Roalson, E.H.; Salamin, N. \& Christin, P.A. 2009 Phylogenomics of $\mathrm{C}_{4}$ photosynthesis in sedge (Cyperaceae): multiple appearances and genetic convergence. Molecular Biology and Evolution 26:1909-1919.

Black, C.C. \& Mollenhauer, H.H. 1971. Structure and distribution and other organelles in leaves with various rates of photosynthesis. Plant Physiology 47: $15-23$.

Brown, W.V. 1958. Leaf anatomy in grass systematics. Botanical Gazette 119: 170-178.

Brown, R.H.; Bouton, J.H.; Rigsby, L. \& Rigler, M. 1983. Photosynthesis of grass species differing in carbon dioxide fixation pathways. VIII. Ultrastructural characteristics of Panicum species in the Laxa group. Plant Physiology 71: 425-431.

Bruhl, J.J. \& Perry, S. 1995. Photosynthetic pathwayrelated ultrastructure of $\mathrm{C}_{3}, \mathrm{C}_{4}$ and $\mathrm{C}_{3}-\mathrm{C}_{4}$ intermediate sedge (Cyperaceae), with special reference to Eleocharis. Australian Journal of Plant Physiology 22: 521-530.

Bruhl, J.J.; Stone, N.E. \& Hattersley, P.W. 1987. C 4 acid decarboxylation enzymes and anatomy in sedge 
(Cyperaceae): first record of NAD-Malic enzyme species. Australian Journal of Plant Physiology 14: 719-728.

Carolin, R.C.; Jacobs, S.W.L. \& Vesk, M. 1977. The ultrastructure of Kranz cells in the family Cyperaceae. Botanical Gazette 138: 413-419.

Edwards, G.E.; Franceschi, V.R. \& Voznesenskaya, E.V. 2004. Single-cell $C_{4}$ photosynthesis versus the dual-cell (Kranz) paradigm. Annual Review of Plant Biology 55:173-96.

Edwards, G.E. \& Voznesenskaya, E.V. 2011. C photosynthesis: Kranz forms and single-cell $\mathrm{C}_{4}$ in terrestrial plants. In: Raghavendra, A.S \& Sage, R.F. (eds.). $\mathrm{C}_{4}$ photosynthesis and related $\mathrm{CO}_{2}$ concentrating mechanisms. Advances in Photosynthesis and Respiration. Vol. 32. Springer Science + Business Media B.V., Dordrecht. Pp 29-61

Estelita, M.E.M. 1992. Origin and structure of the Kranz tissues in Cyperaceae. Boletim de Botânica da Universidade de São Paulo 13: 41-48.

Estelita, M.E.M. 1993. Anatomia dos órgãos vegetativos de Remirea maritima Aubl. (Cyperaceae). Naturalia 18: 123-134.

Estelita-Teixeira, M.E. \& Handro, W. 1987. Kranz pattern in leaf, scape and bract of Cyperus and Fimbristylis species. Revista Brasileira de Botânica 10: 105-111.

Gutierrez M; Gracen, V.E. \& Edwards, G.E. 1974. Biochemical and cytological relationships in $\mathrm{C}_{4}$ plants. Planta 119:279-300

Hatch, M.D.; Kagawa, T. \& Craig, S. 1975. Subdivision of $\mathrm{C}_{4}$-pathway species based on differing $\mathrm{C}_{4}$ acid decarboxylating systems and ultrastructural features. Australian Journal of Plant Physiology 2: 111-128.

Hattersley, P.W. \& Browning, A.J. 1981. Occurrence of the suberized lamella in leaves of grasses of different photosynthetic types. In parenchymatous bundle sheat and PCR (Kranz) sheaths. Protoplasma 109: 371-401.

Kim, I.S.; Pak, J.H.; Seo, B.B. \& Song, S.D. 1999. Ultrastructure of leaves in $\mathrm{C}_{4}$ Cyperus iria and $\mathrm{C}_{3}$ Carex siderosticta. Journal of Plant Biology 42: 213-221.

Laetsch, W.M. 1974. The $\mathrm{C}_{4}$ syndrome: a structural analysis. Annual Review of Plant Physiology 25: 27-52.

Martins, S.; Machado, S.R. \& Alves, M. 2008. Anatomia e ultra-estrutura de Cyperus maritimus Poir. (Cyperaceae): estratégias adaptativas ao ambiente de dunas litorâneas. Acta Botanica Brasilica 22: 289-299.

Martins, S. \& Scatena V.L. 2011. Bundle sheath ontogeny in Kranz and non-Kranz species of Cyperaceae (Poales). Australian Journal of Botany 59: 554-562.

Murphy, L.R.; Barroca, J.; Franceschi, V.R.; Lee, R.; Roalson, E.H.; Edwards, G.E. \& Ku, M.S.B. 2007.
Diversity and plasticity of $\mathrm{C}_{4}$ photosynthesis in Eleocharis (Cyperaceae). Functional Plant Biology 34: 571-580.

R Development Core Team. 2010. R: A language and environment for statistical computing. Vienna: R Foundation for Statistical Computing. Available at <http://www.R-project.org $>$. Access on 27 April 2011.

Reynolds, E.S. 1963. The use of lead citrate at high $\mathrm{pH}$ as an electron-opaque stain in electron microscopy. The Journal of Cell Biology 17: 208-212.

Rodrigues, A.C. \& Estelita M.E.M. 2003. Origin and structure of the Kranz tissue in bracts of Cyperus giganteus Vahl (Cyperaceae). Revista Brasileira de Botânica 26: 445-452.

Sage, R.F. 2002. $\mathrm{C}_{4}$ photosynthesis in terrestrial plants does not require Kranz anatomy. Trends in Plant Science 7: 283-285.

Sage, R.F. 2004. The evolution of $\mathrm{C}_{4}$ photosynthesis. New Phytologist 161: 341-370.

Sage, R.F.; Christin, P.A. \& Edwards, E.J. 2011. The $\mathrm{C}_{4}$ plant lineage of planet, earth. Journal Experimental of Botany 62: 3155-3169.

Sage, R.F.; Sage, T.L. \& Kocacinar, F. 2012. Photorespiration and the evolution of $\mathrm{C}_{4}$ photosynthesis. Annual Review of Plant Biology 63:19-47.

Soros, C.L. \& Bruhl, J.J. 2000. Multiple evolutionary origins of $\mathrm{C}_{4}$ photosynthesis in the Cyperaceae. In: Wilson, K.L. \& Morrison, D.A. (eds.). Monocots: systematics and evolution. CSIRO Publishing, Melbourne. Pp. 629-636.

Tucker, G.C. 1994. Revision of the Mexican species of Cyperus L. (Cyperaceae). Systematic Botany Monographs 43: 1-213.

Ueno, O. 1996. Structural characterization of photosynthetic cells in an amphibious sedge, Eleocharis vivipara, in relation to $\mathrm{C}_{3}$ and $\mathrm{C}_{4}$ metabolism. Planta 199: 382-393.

Ueno, O. 2004. Environmental regulation of photosynthetic metabolism in the amphibious sedge Eleocharis baldwinii and comparisons with related species. Plant Cell Environment 27: 627-639.

Ueno, O. 2013. Ultrastructure and carbon isotope ratios of leaves in $\mathrm{C}_{4}$ species of Rhynchospora (Cyperaceae) that differ in the location of Kranz cells. International Journal of Plant Science 174: 702-709.

Ueno, O.; Samejina, M. \& Koyama, T. 1989. Distribution and evolution of the $\mathrm{C}_{4}$ syndrome in Eleocharis, a sedge group inhabiting wet and aquatic environments, based on culm anatomy and carbon isotope ratios. Annals of Botany 64: 425-438.

Ueno, O.; Takeda, T. \& Maeda, E. 1988. Leaf ultrastructure of $\mathrm{C}_{4}$ species possessing different Kranz anatomical 
types in the Cyperaceae. The Botanical Magazine of Tokyo 101: 141-152.

Voznesenskaya, E.V.; Chuong, S.D.X.; Kiirats, O.; Franceschi, V.R. \& Edwards, G.E. 2005. Evidence that $\mathrm{C}_{4}$ species in genus Stipagrostis, family Poaceae, are NADP-malic enzyme subtype with nonclassical type of Kranz anatomy (Stipagrostoid). Plant Science 168: 731-739.

Yoshimura, Y.; Kubota, F. \& Ueno, O. 2004. Structural and biochemical bases of photorespiration in $\mathrm{C}_{4}$ plants: quantification of organelles and glycine decarboxylase. Planta 220: 307-317. 